\title{
Curcumin Dye-Sensitized Solar Cell
}

\author{
Khalil Ebrahim Jasim ${ }^{1}$, Seamas Cassidy ${ }^{2}$, Feryad Zaki Henari ${ }^{2}$ and Akil Aziz Dakhel ${ }^{1}$ \\ 1. Department of Physics, College of Science, University of Bahrain, P.O. Box 32038, Sakheer, Kingdom of Bahrain \\ 2. Department of Basic Medical Sciences, Royal College of Surgeons in Ireland, Medical University of Bahrain, P.O. Box 15503, \\ Muharraq, Kingdom of Bahrain
}

Received: April 27, 2017 / Accepted: May 08, 2017 / Published: June 30, 2017.

\begin{abstract}
DSSCs (dye sensitized solar cells) are expected to be one of the efficient third generation solar cells that are generating green energy at low production cost since no vacuum systems or expensive equipment are required in their fabrication. In this paper, review of the structure, and operation principles of the dye sensitized solar cell DSSC is outlined. Extraction and optical characterization of Curcumin dye are detailed. Preparation procedures, optical and electrical characterization of the DSSC using Curcumin dye, as well as factors limiting the operation of the DSSC are discussed. Open circuit voltage $V_{o c}=430 \mathrm{mV}$ and short circuit current $I_{\mathrm{sc}}=0.72 \mathrm{~mA}$ from a $3 \mathrm{~cm}^{2}$ curcumin sensitized solar cell is achievable under solar illumination.
\end{abstract}

Key words: Curcumin dye, DSSC, photovoltaic, nanoporous $\mathrm{TiO}_{2}$.

\section{Introduction}

Harnessing energy from sun rays is so far considered as one of the effective solutions in generating green energy. Solar cells are the basic block of solar array where the absorption of light quanta of specific energy results in generation of charge carries. The photogenerated charge carries deliver their energy to some external load where it converted to any other desirable energy form. In 1991, Graetzel and coworkers [1-4] came up with the methodology to dye-sensitize colloidal $\mathrm{TiO}_{2}$ film as a way to fabricate low-cost, high-efficiency solar cells. This was a remarkable development of a non-silicon based solar cell where the overall light-to-electric energy conversion efficiency close to $12 \%$ in diffuse daylight has been reported [4]. Extensive review of DSSC (dye sensitized solar cell) can be found in Refs. [1,2] and references cited therein. It might be possible in the near future to achieve commercial DSSC production for indoor applications such as calculators [1].

Fig. 1 shows a schematic diagram illustrating the

Corresponding author: Khalil Ebrahim Jasim, Ph.D., assistant professor, research fields: photonics, nanotechnology. structure and operation principle of the dye-sensitized cell. The cell is composed of four elements: Conducting electrode and counter conducting electrode, nanostructured $\mathrm{TiO}_{2}$ layer, dye molecules, and electrolyte. The transparent conducting electrode and counter-electrode are coated with a thin conductive and transparent layer of tin dioxide $\left(\mathrm{SnO}_{2}\right)$. Nanocrystalline $\mathrm{TiO}_{2}$ is deposited on the conducting electrode (photoelectrode) to provide the necessary large surface area where dye molecules get adsorbed onto. Upon absorption of sun light dye molecules get excited from the HOMO (highest occupied molecular orbitals) to the LUMO (lowest unoccupied molecular orbitals) state as presented in Eq. (1). Once an electron injected into the conduction band of the wide bandgap semiconductor nanostructured $\mathrm{TiO}_{2}$ film, the dye molecule (photosensitizer) become oxidized, Eq. (2). The injected electron is transported between the $\mathrm{TiO}_{2}$ nanoparticles and then gets extracted to a load where the work done is delivered as an electric energy, Eq. (3). To mediate electron between the $\mathrm{TiO}_{2}$ photoelectrode and the carbon coated counter electrode electrolyte containing $\mathrm{I}^{-} / \mathrm{I}_{3}^{-}$redox ions is used to fill the cell. Therefore, the oxidized dye molecules (photosensitizer) 


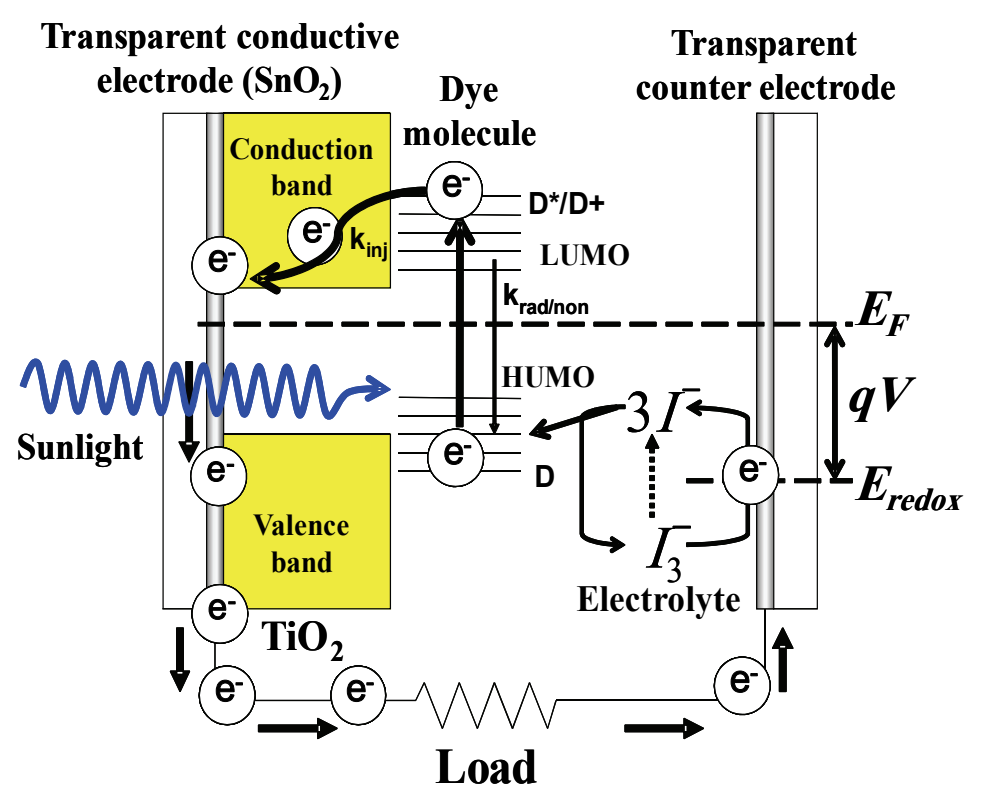

Fig. 1 Schematic diagram illustrating the structure and operation principle of dye-sensitized cell.

are regenerated by receiving electrons from the $\mathrm{I}^{-}$ion redox mediator that will oxidized to $\mathrm{I}_{3}{ }^{-}$(Tri-iodide ions), Eq. (4). The $\mathrm{I}_{3}^{-}$substitutes the donated electron internally with that from the external load and gets reduced back to I' ion, Eq. (5). Therefore, generation of electric power in DSSC causes no permanent chemical change or transformation.

$$
\begin{gathered}
\mathrm{D}+\mathrm{h} v \rightarrow \mathrm{D}^{*} \\
\mathrm{D}^{*}+\mathrm{TiO}_{2} \rightarrow \mathrm{D}^{+}+\mathrm{e}^{-}\left(\mathrm{TiO}_{2}\right) \\
\mathrm{e}^{-}\left(\mathrm{TiO}_{2}\right)+\text { Electrode } \rightarrow \\
\mathrm{TiO}_{2}+\mathrm{e}^{-}(\text {Electrode })+\text { Energy } \\
\mathrm{D}^{+}+\mathrm{e}^{-} \rightarrow \mathrm{D}+\mathrm{I}_{3}^{-} \\
\left.2 \mathrm{e}^{-} \text {(Electrode }\right)+\mathrm{I}_{3}{ }^{-} \rightarrow 3 \mathrm{I}^{-}+\text {Electrode }
\end{gathered}
$$

The conducting electrodes are prepared such that they posses low sheet resistance and very high transparency in order to facilitate high solar cell performance. For the counter electrode of the cell to have high electro-catalytic activity it is coated with carbon (sooth) just before assembling the cell.

Also illustrated in Fig. 1, the maximum potential produced by the cell is determined by the energy separation between the electrolyte chemical potential $\left(E_{\text {redox }}\right)$ and the Fermi level of the $\mathrm{TiO}_{2}\left(E_{\mathrm{F}}\right)$. The smaller the energy separation between the HOMO and LUMO ensures absorption of low energy photons in the solar spectrum. Therefore, the photocurrent level is dependent on the HOMO-LUMO levels separation. This is analogous to inorganic semiconductors bandgap energy $E_{\mathrm{g}}$. In fact, effective electron injection into conduction band of $\mathrm{TiO}_{2}$ is highly enhanced with the increase of energy separation of LUMO and the bottom of the $\mathrm{TiO}_{2}$ conduction band. Also, for the HOMO level to effectively accept the donated electrons from the redox mediator, the energy difference between the HOMO and redox potential must be more positive [1].

Since the overall DSSC efficiency is proportional to electron injection efficiency in the wide bandgap nanostructured semiconductor, investigations have been escalated over the past decade where $\mathrm{ZnO}$ nanowires, for example, have been developed to replace both porous and $\mathrm{TiO}_{2}$ nanoparticles based solar cells [5]. Also, metal complex and novel man made dyes have been proposed [6-8]. However, their processing and synthesization is a complicated and costly process [9-15]. In this paper, we report for the first time the sensitization of nanoporous $\mathrm{TiO}_{2}$ layer using Curcumin solutions. Details of the preparation of Curcumin dye, characterization of its optical properties, and investigation of photovoltaic action via sensitizing nanoporous $\mathrm{TiO}_{2}$ are stated. 


\section{Experimental Method}

The nanoporous $\mathrm{TiO}_{2}$ film was prepared by following the preparation methodology detailed in Refs. $[1,3,4,14,16]$. A suspension of $\mathrm{TiO}_{2}$ was prepared by adding $9 \mathrm{~mL}$ of nitric acid solution of $\mathrm{pH} 3-4(1 \mathrm{~mL}$ increment) to $6 \mathrm{~g}$ of colloidal $\mathrm{P} 25 \mathrm{TiO}_{2}$ powder in mortar and pestle. While grinding, $8 \mathrm{~mL}$ of distilled water (in $1 \mathrm{~mL}$ increment) was added to get a white-free flow-paste. Finally, a drop of transparent surfactant was added in $1 \mathrm{~mL}$ of distilled water to ensure coating uniformity and adhesion to the transparent conducting glass electrode. The ratio of the nitric acid solution to the colloidal $\mathrm{P} 25 \mathrm{TiO}_{2}$ powder is a critical factor for the cell performance. If the ratio exceeds a certain threshold value the resulting film becomes too thick and has a tendency to peel off. On the other hand, a low ratio reduces appreciably the efficiency of light absorption.

As detailed in Ref. [17] curcumin is a yellow pigment. It is a natural component of rhizome called turmeric, of the plant Curcuma Longa $\mathrm{L}$. The powdered rhizome of this plant, called turmeric In addition to its use in curries, flavoring and coloring of the diet, Curcumin has been used as a medicine for treatments of inflammation, skin wound and cough, however its anticancer properties have generated a great interest and results in many publications. Chemical analysis of the extraction products of this powder by a variety of solvent mixtures has shown the principal components to be curcumin [1,7-bis(4-hydroxy-3-methoxyphenyl)-1,6-heptadiene3,5-dione], demethoxycurcumin [1-(4-hydroxyphenyl) -7-(4-hydroxy-3-methoxyphenyl)-1,6-heptadiene-3,5dione] and bisdemethoxycurcumin [1,7-bis(4-hydroxyphenyl)-1,6-heptadiene-3,5-dione]

[18]. The structures of the above molecules are shown in Fig. 2. In fact, the curcumin has a $\beta$-diketone group which equilibrates to a more stable keto enol tautomeric conformation which can exist in cis and trans isomers [19-21]. Fig. 3 shows typical structures of different keto and keto enol forms [22].
For the purposes of this investigation, turmeric was extracted using acetonitrile as in the following procedures: Turmeric $(20 \mathrm{~g})$ was added to acetonitrile $(100 \mathrm{~mL})$ and stirred for 6 hours. The yellow solution was filtered under vacuum through a bed of charcoal and silica gel in a 1:1 mixture. The solvent was evaporated at ambient temperature to give a glass like residue with a yield of $0.62 \mathrm{~g}$. A homogonous solution is prepared by dissolving $0.255 \mathrm{~g}$ in $100 \mathrm{~mL}$ of methanol grade $99.9 \%$.

Doctor blade method was employed in deposition of $\mathrm{TiO}_{2}$ suspension which was applied uniformly on a cleaned (rinsed with ethanol) electrode plate. The $\mathrm{TiO}_{2}$ film was allowed to dry and then annealed at approximately $450{ }^{\circ} \mathrm{C}$ (in a well ventilated zone) for about 15 minutes to form a porous, large surface area $\mathrm{TiO}_{2}$ film. The film must be allowed to cool down slowly to room temperature. This is a necessary condition to remove thermal stresses and avoid cracking of the glass or peeling off the $\mathrm{TiO}_{2}$ film. Investigation of the formation of nanocrystalline $\mathrm{TiO}_{2}$ film was confirmed by scanning electron micrograph SEM. $\mathrm{TiO}_{2}$ nanocrystalline layer was stained with the dye for approximately a day, and then washed with distilled water and ethanol to ensure the absence of water in the film after removal of the residual dye. The counter electrode was coated with graphite (sooth) that acts as a catalyst in redoxing the dye. Both the photo and the counter electrode were clamped together and drops of electrolyte were applied to fill the clamped cell. The electrolyte used consists of an organic solvent

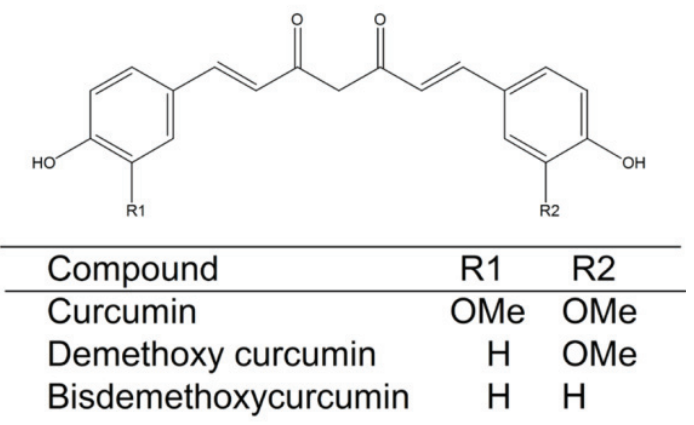

Fig. 2 Chemical structure of the curcumin molecules. 
Different keto forms<smiles>[R]C(=O)CC([R])=O</smiles><smiles>[R]C(=O)CC([R])=O</smiles><smiles>[R]C(=O)CC([R])=O</smiles>

Different enol forms<smiles>[R]C(=O)C=C([R])O</smiles><smiles>[R]C1=CC([R])=[CH+]O1</smiles><smiles>[R]C(=O)C=C([R])O</smiles><smiles>[R]C(=O)C=C([R])O</smiles><smiles>[R]C(=O)C=C([R])O</smiles>

Different R groups that may exist.<smiles>C=Cc1ccc(O)c(OC)c1</smiles><smiles>C=Cc1ccc(O)c(O)c1</smiles>

Fig. 3 Keto-enol tautomerism of Curcumin.

containing a redox couple (traditionally the iodide/triiodide $\left[\mathrm{I}^{-} / \mathrm{I}_{3}{ }^{-}\right]$couple). The measurements of open-circuit voltage and short-circuit current have been performed using solar simulator. UV and IR cutoff filters but no AR coatings on the photoelectrode have been used.

\section{Results and Discussions}

The extracted curcumin dye solutions have been optically characterized by measuring its absorbance using dual beam UV-VIS spectrophotometer (Shimadzu, model UV-3101). Typical example of light harvesting efficiency ( $\mathrm{LHE}=1-10^{-\mathrm{A}}$, where $\mathrm{A}$ is the absorbance) measurements is shown in Fig. 4. In this figure, curcumin solution exhibits 100\% LHE for photons with wavelength between $300 \mathrm{~nm}$ to $500 \mathrm{~nm}$, and it sharply drops less than $10 \%$ beyond $600 \mathrm{~nm}$. Hence, red and near infrared portion of the solar spectrum is not absorbed by curcumin molecules. The

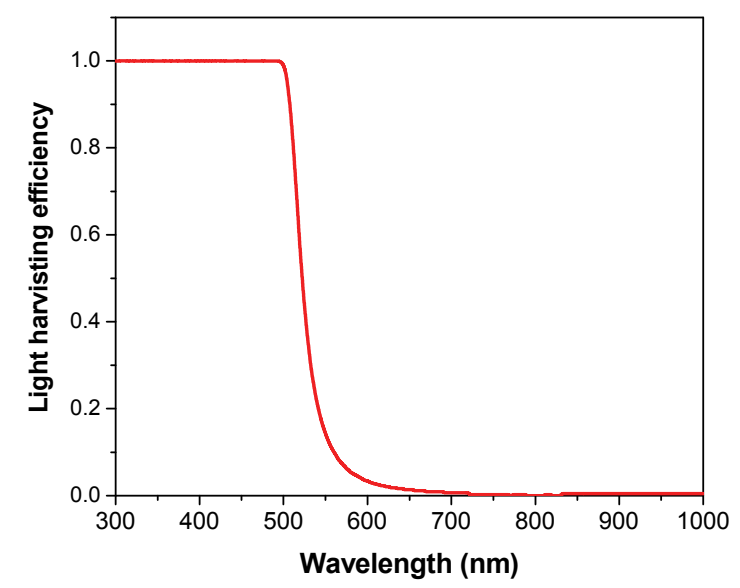

Fig. 4 Light harvesting efficiency vs. wavelength for curcumin dye. 
incident photon to current conversion efficiency IPCE is defined as:

$$
\operatorname{IPCE}=\operatorname{LHE} \Phi_{\text {inj }} \eta_{\mathrm{c}}
$$

where $\Phi_{\text {inj }}$ is the quantum yield of electron injection and $\eta_{c}$ is the collection efficiency of the injected electrons at the back contact. Therefore, the IPCE equals the LHE if both $\Phi_{\text {inj }}$ and $\eta_{\mathrm{c}}$ are close to $100 \%$. Thus, the investigated dye extracts are suggested to be a promising natural dye sensitizer for single junction DSSC.

The formation of nanocrystalline $\mathrm{TiO}_{2}$ particles is greatly affected by $\mathrm{TiO}_{2}$ suspension preparation procedures as well as by the annealing temperature. The porosity of the $\mathrm{TiO}_{2}$ is an essential not only to ensure high roughness factor, but also to enhance the penetration of the redoxing ions into the film. It was found that a sintered $\mathrm{TiO}_{2}$ film at temperatures lower than the recommended $450{ }^{\circ} \mathrm{C}$ resulted in cells that generate unnoticeable electric current even in the $\mu \mathrm{A}$ level. Moreover, $\mathrm{TiO}_{2}$ layer degradation in this case was fast and cracks form after a short period of time when the cell is exposed to illumination.

Table 1 presents some of the measured and calculated parameters of the assembled photovoltaic cells. Due to light reflection and absorption by the conductive photoelectrode and scattering nature of the nanostructured $\mathrm{TiO}_{2}$, the measured transmittance of the photoelectrode shows on the average $10 \%$ of the solar simulator spectrum (AM 1.5) is allowed. On the average, the active area of the photovoltaic cell is 3 $\mathrm{cm}^{2}$.

The $I-V$ characteristics shown in Fig. 5 indicate the presences of a noticeable series resistance. Such series resistance affects cell performance. Capacitive effect is also existed due to nature of cell layer structure.

Generally speaking, the performance of the studied photovoltaic cells is affected by many factors. Firstly, the dye structure must possess several carbonyl $(\mathrm{C}=\mathrm{O})$ or hydroxyl (-OH) groups capable of complexing to the Ti (IV) sites on the $\mathrm{TiO}_{2}$ surface [23]. This in fact explains why dyes from grapes are not good sensitizer, while the California blackberries (Rubus ursinus) are excellent source of dye for sensitization [14, 24].

Secondly, the redoxing electrolyte needs to be chosen such that the reduction of $\mathrm{I}_{3}{ }^{-}$ions by injection of electrons is fast and efficient (see Fig. 1). This arise from the fact that the dependence of both hole transport and collection efficiency on the dye-cation reduction and $\mathrm{I}^{-} / \mathrm{I}_{3}{ }^{-}$redox efficiency at counter electrodes are to be considered [25]. As a matter of fact, besides limiting cell stability due to evaporation, liquid electrolyte inhibits fabrication of multi-cell modules since module manufacturing requires cells be connected electrically yet separated chemically [26, 27]. To improve the performance of the cell we suggest replacing the liquid electrolyte with a solid state one that provides a better sealing of the cell $[28,29]$.

Thirdly, the thickness of nanocrystalline $\mathrm{TiO}_{2}$ film must be few tens of micrometers $(<30 \mu \mathrm{m})$ to ensure that the diffusion length $L_{n}=\sqrt{D_{n} \tau_{n}}$ of the photoelectrons is greater than that of the nanoporous $\mathrm{TiO}_{2}$ layer $[1,30]$. To increase photgenerated electron diffusion length, studies suggest replacing the nanoparticles film with an array of single crystalline nanowires or nanosheets in which the electron transport increases by several orders of magnitude [5, 32-34].

Table 1 Measured and calculated parameters of the assembled solar cells using different natural dye sensitizers.

\begin{tabular}{lllll}
\hline Dye & $V_{\text {oc }}(\mathrm{V})$ & $I_{\text {sc }}(\mathrm{mA})$ & $F F(\%)$ & $\eta(\%)$ \\
\hline Curcumin & 0.432 & 0.720 & 40 & 0.41 \\
Bahraini Henna 8 g & 0.410 & 0.906 & 36.3 & 0.450 \\
${\text { Yemeni Henna } 4.2 \mathrm{~g}^{\mathrm{b}}}_{\text {Raspberries }^{\mathrm{a}}}$ & 0.500 & 0.414 & 27.6 & 0.191 \\
Cherries in Methanol $^{\mathrm{a}}$ & 0.360 & 0.566 & 45.5 & 0.309 \\
\hline
\end{tabular}

\footnotetext{
${ }^{\mathrm{a}}$ Ref. [16], ${ }^{\mathrm{b}}$ Ref. [31].
} 


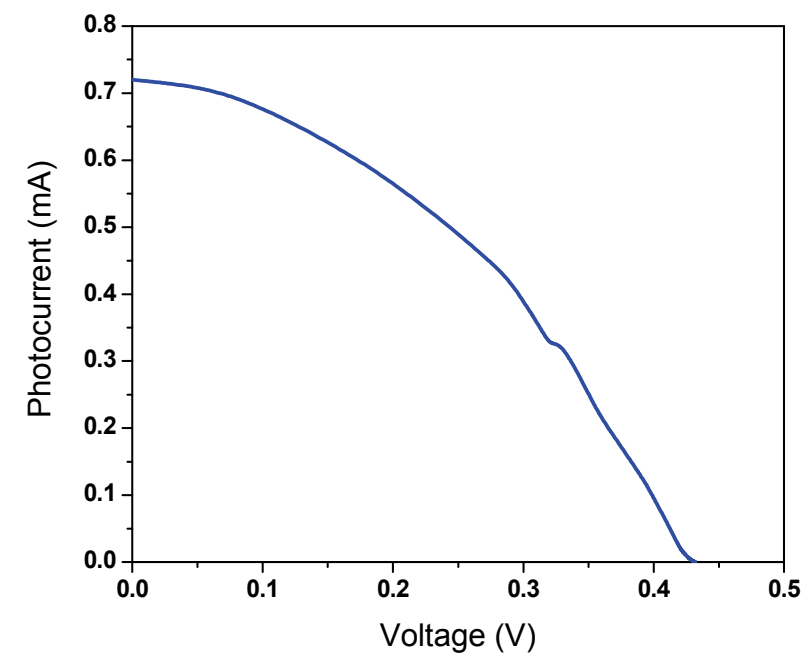

Fig. 5 Typical $I-V$ characteristics for an assembled Curcumin sensitized nanoporous $\mathrm{TiO}_{2}$ solar cell.

Finally, dark current in DSSC is mainly due to the loss of the injected electron from nanostructured $\mathrm{TiO}_{2}$ to $\mathrm{I}_{3}{ }^{-}$(the hole carrier in solution electrolyte). Reduction of dark current enhances the open circuit voltage of the cell, and one successful way to suppress dark current is to use of coadsorbates on the nanostructured $\mathrm{TiO}_{2}$ surface. Therefore, to achieve further improvement of the performance of DSSC cell many researchers have suggested replacing the liquid electrolyte with a solid state one that provides a better sealing of the cell $[28,29]$ and fabrication of large area modules with efficiency above $12 \%$. The success of Sony in 2010 to present a DSSC module with efficiency close to $10 \%$ is one of the driving achievements toward fabrication of outdoor larger area modules that can be integrated in green buildings. Also, as presented for example by Dyesol ${ }^{\mathrm{TM}}$, development of flexible transparent substrate (polymer-based) will transform DSSCs industry toward mass production and commercialization of single cell or mini modules for indoor and personal appliances.

\section{Conclusions}

In summary, we have demonstrated the sensitization of nanoporous $\mathrm{TiO}_{2}$ with Curcumin dye extract. Dye extract showed a high level of absorbance in the UV, and visible regions of the solar spectrum; a similar behavior is possessed by pomegranate and Bahraini raspberries. Therefore, these natural dyes extracts are potentially capable of replacing some of the man made dyes used as sensitizer in nanocrystalline $\mathrm{TiO}_{2}$ photovoltaic cells. Both the preparation of nanocrystalline $\mathrm{TiO}_{2}$ layer and the nature of redoxing electrolyte must be optimized to enhance collection efficiency of the cell. We do suggest other nanostructure configurations such as nanocrystalline rods or dendrimers structures. Other factors during dye extraction such as solvent choice and temperature of extraction must be investigated.

Due to the following advantages of DSSC over semiconductor based solar cells: bifacial configuration, efficiency less sensitive to angle of incidence, transparency for power windows, and color variation by selection of the dye; DSSC are expected to be a choice in building integrated photovoltaics BIPV. Also, success in fabrication of flexible substrate and screen printing of wide bandgap nanostructured semiconductor will facilitate mass production and commercialization of DSSC.

\section{Acknowledgments}

The authors are greatly indebted to the Royal College of Surgeons in Ireland, Medical University of Bahrain for financial support and characterization facilities at the University of Bahrain.

\section{References}

[1] Hara, K., and Arakawa, H. 2003. "Dye-Sensitized Solar Cells." In Handbook of Photovoltaic Science and Engineering, edited by Luque, A., and Hegedus, S. Hoboken: John Wiley \& Sons, Ltd., ISBN: 0-471-49196-9.

[2] Kalyanasundaram, K., and Gratzel, M. 1998. "Applications of Functionalized Transition Metal Complexes in Photonic and Optoelectronic Devices." Coordination Chemistry Reviews 177 (1): 347-414.

[3] Nazerruddin, M. K., Kay, A., Ridicio, I., Humphry-Baker, R., Mueller, E., Liska, P., Vlachopoulos, N., and Gratzel, M. 1993. "Conversion of Light to Electricity by cis-X2bis (2,2'-Bipyridyl-4,4'-Dicarboxylate) Ruthenium (II) Charge-Transfer Sensitizers (X $=\mathrm{Cl}-, \mathrm{Br}-, \mathrm{I}-, \mathrm{CN}-$, and 
SCN-) on Nanocrystalline $\mathrm{TiO}_{2}$ Electrodes." Journal of the American Chemical Society 115 (14): 6382-90.

[4] O'Regan B., and Gratzel, M. 1991. "A Low Cost, High-Efficiency Solar Cell based on Dye-Sensitized Colloidal $\mathrm{TiO}_{2}$ Films.” Nature 353 (October ): 737-40.

[5] Law, M., Greene, L. E., Johnson, J. C., Saykally, R., and Yang, P. D. 2005. "Nanowire Dye-Sensitized Solar Cells." Nature Materials 4 (May): 455-9.

[6] Hasselmann, G., and Meyer, G. 1999. "Sensitization of Nanocrystalline $\mathrm{TiO}_{2}$ by $\mathrm{Re}(\mathrm{I})$ Polypyridyl Compounds." Zeitschrift fur Physikalische Chemie 212 (1): 39-44.

[7] Islam, A., Hara, K., Singh, L. P., Katoh, R., Yanagida, M., Murata, S., Takahashi, Y., Sugihara, H., and Arakawa, H. 2000. "Dual Electron Injection from Charge-Transfer Excited States of $\mathrm{TiO}_{2}$ anchored Ru(II)-4,4'-Dicarboxy-2,2'-Biquinoline Complex." Chemistry Letters 29 (5): 490-1.

[8] Yang, M., Thompson, D., and Meyer, G. 2000. "Dual Sensitization Pathways of $\mathrm{TiO}_{2}$ by $\mathrm{Na}_{2}\left[\mathrm{Fe}(\right.$ bpy $\left.)(\mathrm{CN})_{4}\right]$." Inorganic Chemistry 39 (17): 3738-9.

[9] Amao, Y., and Komori, T. 2004. "Bio-photovoltaic Conversion Device Using Chlorine- $\mathrm{e}_{6}$ Derived from Chlorophyll from Spirulina Adsorbed on a Nanocrystalline $\mathrm{TiO}_{2}$ Film Electrode." Biosensors Bioelectronics 19 (8): 843-7.

[10] Garcia, C. G., Polo, A. S., and Iha, N. Y. 2003. "Fruit Extracts and Ruthenium Polypyridinic Dyes for Sensitization of $\mathrm{TiO}_{2}$ in Photoelectrochemical Solar Cells." Journal of Photochemistry and Photobiology A: Chemistry 160 (1-2): 87-91.

[11] Hao, S., Wu, J., Huang, Y., and Lin, J. 2006. "Natural Dyes as Photosensitizers for Dye-Sensitized Solar Cell." Solar Energy 80 (2): 209-14.

[12] Polo, A. S., and Iha, N. Y. 2006. "Blue Sensitizers for Solar Cells: Natural Dyes from Calafate and Jaboticaba." Solar Energy Materials and Solar Cells 90 (13): 1936-44.

[13] Kumara, G. R. A., Kanebo, S., Okuya, M., Onwaona-Agyeman, B., Konno, A., and Tennakone, K. 2006. "Shiso Leaf Pigments for Dye-Sensitized Solid-state Solar Cell." Solar Energy Materials and Solar Cells 90 (9): 1220-6.

[14] Smestad, G. P. 1998. "Education and Solar Conversion: Demonstrating Electron Transfer." Solar Energy Materials and Solar Cells 55 (1-2): 157-78.

[15] Yanagida, S., Senadeera, G. K. R., Nakamura, K., Kitamura, T., and Wada, Y. 2004. "Polythiophene-Sensitized $\mathrm{TiO}_{2}$ Solar Cells." Journal of Photochemistry and Photobiology A: Chemistry 166 (1-3): 75-80.

[16] Jasim, K. E. 2012. "Natural Dye-Sensitized Solar Cell Based on Nanocrystalline $\mathrm{TiO}_{2}$." Sains Malaysiana 41 (8): 1011-6.
[17] Henari, F. Z., Cassidy, S., Jasim, K. E., and Dakhel, A. A. 2013. "Nonlinear Refractive Index Measurements of Curcumin with CW Laser." Journal of Nonlinear Optical Physics \& Materials 22 (2): 216-9.

[18] Peret-Almeida, L., Cherubino, A. P. F., Alves, R. J., Dufosse, L., and Gloria, M. B. A. 2005. "Separation and Determination of the Physico-Chemical Characteristics of Curcumin, Demethoxycurcumin and Bisdemethoxycurcumin." Food Research International 38 (8-9): 1039-44.

[19] Wright, J. S., and Mol, J. 2002. "Predicting the Antioxidant Activity of Curcumin and Curcuminoids." Journal of Molecular Structure: THEOCHEM 591 (1-3): 207-17.

[20] Cornaco, P., Claramunt, R. M., Bouissane, L., Alkorta, I., and Alkorta, J. 2008. "A Study of the Tautomerism of $\beta$-Dicarbonyl Compounds with Special Emphasis on Curcuminoids." Tetrahedron 64 (35): 8089-94.

[21] Kolev, T. M., Velcheva, E. A., Stamboliyska, B. A., and Spiteller, M. 2005. "Dft and Experimental Studies of the Structure and Vibrational Spectra of Curcumin." International Journal of Quantum Chemistry 102 (6): 1069-79.

[22] Indira Priyadarsini, K. 2009. "Photophysics, Photochemistry and Photobiology of Curcumin: Studies from Organic Solutions, Bio-mimetics and Living Cells." Journal of Photochemistry and Photobiology C: Photochemistry Reviews 10 (2): 81-95.

[23] Tennakone, K., Kumara, G., Kottegota, I., and Wijayantha, K. 1997. "The Photostability of Dye-Sensitized Solid State Photovoltaic Cells: Factors Determining the Stability of the Pigment in a Nanoporous n- $\mathrm{TiO}_{2} /$ cyanidin/p-CuI Cell." Semiconductor Science and Technology 12 (1): 128.

[24] Cherepy, N. J., Smestad, G. P., Gratzel, M., and Zhang, J. Z. 1997. "Ultrafast Electron Injection: Implications for a Photoelectrochemical Cell Utilizing an Anthocyanin Dye-Sensitized $\mathrm{TiO}_{2}$ Nanocrystalline Electrode.” Journal of Physical Chemistry B 101 (45): 9342-51.

[25] Yanagida, S. 2006. "Recent Research Progress of Dye-Sensitized Solar Cells in Japan." Comptes Rendus Chimie 9 (5-6): 597-604.

[26] Matsumoto, M., Wada, Y., Kitamura, T., Shigaki, K., Inoue, T., Ikeda, M., and Yanagida, S. 2001. "Fabrication of Solid-State Dye-Sensitized $\mathrm{TiO}_{2}$ Solar Cell Using Polymer Electrolyte." Bulletin of the Chemical Society of Japan 74 (2): 387-93.

[27] Tennakone, K., Perera, V. P. S., Kottegoda, I. R. M., and Kumara, G. 1999. "Dye-Sensitized Solid State Photovoltaic Cell Based on Composite Zinc Oxide/tin (IV) Oxide Films." Journal of Physics D: Applied Physics 32 (4): 374-9. 
[28] Kruger, J., Plass, R. M., Gratzel, M., Cameron, P. J., and Peter, L. M. 2003. "Charge Transport and Back Reaction in Solid-State Dye-Sensitized Solar Cells: A Study Using Intensity-Modulated Photovoltage and Photocurrent Spectroscopy." Journal of Physical Chemistry B 107 (31): 7536-9.

[29] Stthatos, E., Lianos, P., Vuk, A. S., and Orel, B. 2004. "Optimization of a Quasi-Solid-State Dye-Sensitized Photoelectrochemical Solar Cell Employing a Ureasil/Sulfolane Gel Electrolyte." Advanced Functional Materials 14 (1): 45-8.

[30] Jasim, K. E., and Hassan, A. M. 2009. "Nanocrystalline $\mathrm{TiO}_{2}$ Based Natural Dye Sensitized Solar Cells." International Journal of Nanomanufacturing 4 (1/2/3/4): 242-7.

[31] Jasim, K. E., Al Dallal, S., and Hassan, A. M. 2011. "Natural Dye-Sensitised Photovoltaic Cell Based on
Nanoporous $\mathrm{TiO}_{2}$." International Journal of Nanoparticles 4 (4): 359-68.

[32] Kopidakis, N., Benkstien, K. D., van de Lagemaat, J., and Frank, A. J. 2003. "Influence of the Percolation Network Geometry on Electron Transport in Dye-Sensitized Titanium Dioxide Solar Cells." Journal of Physical Chemistry B 107 (31): 7759-67.

[33] Noack, V., Weller, H., and Eychmuller, A. 2002. "Electron Transport in Particulate $\mathrm{ZnO}$ Electrodes: A Simple Approach.” Journal of Physical Chemistry B 106 (34): 8514-23.

[34] Xiang, J. H., Zhu, P. X., Masuda, Y., Okuya, M., Kaneko, S., and Koumoto, K. 2006. "Flexible Solar-Cell from Zinc Oxide Nanocrystalline Sheets Self-assembled by an In-situ Electrodeposition Process." Journal of Nanoscience and Nanotechnology 6 (6): 1797-801. 